\section{Earliest Monumental Remains in Iraq}

THE joint expedition of the American School of Oriental Studies and the University of Pennsylvania, in continuing the excavation of the mound site of Tepe Gawra in Mesopotamia, upon which it has been engaged now for several seasons, has uncovered some remarkable remains of a monumental character in the level of stratification now being explored. This level is the thirteenth from the surface in the series of some twenty strata of deposits of which preliminary exploration showed the mound to be composed before virgin soil was reached. Its culture is that of the 'painted pottery' people, of which evidence has been found wide-spread over early western Asia and the ancient East, from southern Russia to China, and dated at approximately 4000 B.c. and later. In a recent report from Prof. E. A. Speiser, field director of the expedition, according to a communication circulated by Science Service, Washington, it is stated that the expedition has discovered the acropolis of the city. It consists of a northern temple, eastern shrine and central temple, which with other buildings surround an open square, or court, paved with gravel covered with stamped clay. In the central temple, all the rooms show traces of a purple-red paint. The buildings are of an imposing character, and being the earliest known of their kind, carry back the practice of monumental architectural art to a much earlier phase of civilization than had hitherto been thought, while 'Tepe Gawra is shown to be the centre of an organized civic life, on a scale and of a kind for which hitherto there had been no evidence in connexion with the presumedly primitive people of the stone age to whom the painted pottery had been ascribed.

\section{Soil Drift in South Australia}

Mr. F. N. RATCLIFFE, of the Council for Scientific and Industrial Research, Melbourne, has sent a long communication, for which space cannot be found, discussing an article in NATURE of December 19, based on his recent report on wind erosion (drift soil) in the arid pastoral belt of South Australia. Mr. Ratcliffe appears to hold the opinion that the processes taking place in that part of the world differ from the causes which have, and are, producing the man-made desert in other regions. The factors responsible for the destruction of the vegetation in Australia are drought, overgrazing by stock and the rabbit. The extension of the Sahara and the dust bowl in America are (omitting the rodent) being brought about by the same causes--excessive cultivation or grazing, or both combined. But the word 'drought' as used in Australia and America requires definition. This is the chief factor in the case. The actual results of the over-utilization are the same, whether the land is actually covered up by sand, or the top soil is blown away, or the soil deteriorates in situ: the spring water-level is lowered in the soil, not by drought as ordinarily understood by that word, but by the desiccation brought about by the acts of man. The end is a desert, and the water disappears from the surface and sinks to varying depths in the soil. As regards wind erosion, that is, dust storms, few travellers or inquirers who have studied desert regions, many of them man-made, can have failed to become acquainted with desert clouds of that type, whether consisting of sand or blown soil of valuable types. Mr. Ratcliffe has conceived the idea that the erosion or drift in Australia is some. thing apart. It would appear to be only a type.

\section{Oceanography in New South Wales}

THE seasonal fluctuations in nutrient salts in European coastal waters and their bearing on the production of phytoplankton and ultimately on the fertility of the sea are now well understood. However, there are still huge areas of the waters of the world, including those adjacent to civilized countries carry. ing on original research, about which nothing whatever is known. Off the New South Wales coast, W. J. Dakin and A. N. Colefax ("Observations on the Seasonal Changes in Temperature, Salinity, Phosphates, and Nitrate Nitrogen and Oxygen of the Ocean Waters on the Continental Shelf off New South Wales and the Relationship to Plankton Production", Proc. Linn. Soc. New South Wales, 60, 303-314; 1935. Sydney University Reprints, Ser. XIII (Zoology), 3 , No. 8 ; 1936) have now found complete exhaustion of both phosphate and nitrate by spring and autumn phytoplankton outbursts. The depletion of nitrate persists through the summer as in the seas around Great Britain, but phosphate is replenished more quickly. On the whole, nutrient salts are less than were found in the English Channel in the nineteen twenties but are not very different from the reduced quantities found there now. It is to be hoped that the investigations will be continued for a number of years to discover whether similar long-period fluctuations take place in Australian temperate waters, and further, that a well-found ship may be obtained to permit of investigations over a wider area unhandicapped by the difficulties of carrying on exact scientific work in the open ocean from the decks of a small yacht such as that at present in use.

\section{Electricity Supply Tariffs}

THE question of the standardization of electricity supply tariffs is of interest to many. A recent paper read by J. F. M. Mellor to the Students' Section of the Institution of Flectrical Engineers on the basis on which those tariffs are founded is both a timely and a useful one. There are many difficulties in the way of getting an equitable solution to some of these problems. Take the case, for example, of an 'isolated consumer', that is, one who is at a considerable distance from the supply mains. In this case it is quite customary to charge the consumer the whole or part of the interest and depreciation on the capital cost of the mains extensions to his premises. It is reasonable, therefore, to expect that in the event of other consumers being connected on to these extensions, some refund should be made to the original consumer, and this should be mentioned in his agreement. The difficulty arises as to the period of time after the laying of the mains before the 
liability of the supply authority ceases. Another difficulty is that the time of the peak load varies owing to the great increase in domestic water heaters and thermal storage apparatus which has recently occurred. In many places, when making a longterm agreement, no period of the day or night can now be regarded as 'off peak' and allowed for at a cheaper rate. A supply for a fixed number of hours per day at the lower rate can be arranged, but this is not so attractive to the consumer. Everyone agrees that standardization is desirable, but there are difficulties in the way until the many small undertakings in the country are amalgamated with the larger authorities. When this comes, a lowering of the tariffs will follow in the country districts, since the 'diversity' of the combined load will be increased and so less spare plant be required. A broader policy also can be adopted.

\section{Education of Unemployed in the United States}

Educational needs of unemployed young people are discussed in Bulletin, 1936, No. 18-3, entitled "Education for those out of School", recently published by a standing committee established two years ago by the United States Office of Education in cooperation with other Government agencies and educational leaders for the purpose of assisting communities and youth agencies, with the aid of youths themselves, to solve some of the problems overshadowing their outlook to-day (Washington, D.C. : Government Printing Office, 1936. 10 cents). This pamphlet, the third of a series of six bulletins issued by the committee, describes some of the plans that have proved serviceable to unemployed persons of ages 16-24 years. Of the twenty million persons of those ages in the United States, some four million are in full-time schools and colleges, nearly eight million are employed on full- or part-time jobs, and nearly five million are seeking employment.

ONe conclusion arrived at by the committee is that there is a large unsatisfied demand on the part of these young people, and especially girls, for training which will lead to, if it is not combined with, earning capacity. Another conclusion is that in the case of rural youth a combination of educational and recreational schemes is essential; neither the strictly educational nor the strictly recreational schemes have been found successful. Again, informal rather than formal procedures are desirable, and units of instruction and courses should be of short duration; for example, twelve to fifteen weeks to a unit with twohour meetings once or twice a week. Above all, instruction should have specific goals and arouse a sense of achievement or arrival at a determined destination, and work should be so planned as to give a sense of continuity. Particulars are given of numerous schemes of vocational training for out-ofschool youth which have been found to work well. The other bulletins of this series are entitled : how communities can help, leisure for living, vocational guidance for those out of school, finding jobs, and health protection.

\section{Scottish Technical Colleges}

Tне Royal Technical College, Glasgow, reviews, in its report on the work of the session 1935-36, its own progress since its constitution in 1886 by the amalgamation of Anderson's College with a number of other separate institutions. In these fifty years, the number of its day students has increased from 124 to 1,001 and its gross income from $£ 9,248$ to $£ 81,837$. Among its more important developments during that time are the establishment of departments of architecture, textile manufacture, navigation, sugar manufacture, pharmacy and bakery, and the erection and equipment of new buildings at a cost of $£ 400,000$. Its counterpart in Edinburgh, the Heriot-Watt College, has far fewer day students (364) but its evening class students $(2,460)$ are nearly as many as those of the R.T.C. Both colleges co-operate with city and county education committees in regard to the provision in continuation schools of courses preparatory to college courses. The Edinburgh college, however, records a serious falling off in the number of students from city continuation schools, and attributes this decline to lack of interest on the part of employers.

\section{Heat and Power Station in Northern Russsia}

According to the Soviet Union Year Book Press Service, Grand Buildings, Trafalgar Square, W.C.2, plans have been completed for the building of a large heat and power station about twenty miles from Kotlas, a busy town in the northern province of the U.S.S.R. It will be built in virgin forest, near the site where building work is now proceeding in connexion with cellulose, chemical and wood-working enterprises for the Soviet timber and paper industry. This year the first section of the station with a capacity of $24,000 \mathrm{~kW}$. will be brought into operation. It will have an annual output of $1 \cdot 2$ million tons of steam. Fuel will be provided by gas generated by pitch, a by-product from the local timber and chemical industries. Four boilers will produce 60-80 tons of steam per hour, at a pressure of 35 atmospheres, the steam passing into turbines of $12,000 \mathrm{~kW}$. each. These boilers are fitted with special fuel jets for the new form of fuel. The turbines can run at various steam pressures, depending on the requirements of production.

\section{The Midwifery Service}

The annual report of the Central Midwives Board for the year ended March 31, 1936, has been published (London : H.M. Stationery Office. 2d. net). It shows that there were 62,064 women on the midwives roll, an increase of 3,100 on the total for the previous. year, although only a little more than a quarter of the total number of qualified midwives are actually engaged in the practice of their profession. The report states that during the year the Board approved a. final draft of new rules for training and examination, which has since been submitted to the Minister of Health. The report also includes notes on interesting decisions given by the Board during the year on midwifery etiquette and practice. 